\title{
Tungsten(VI) Oxide Supported Rhodium(0) Nanoparticles Used as Catalyst in Hydrogenation of Benzene at Room Temperature
}

\author{
Oda Sıcaklığında Benzen Hidrojenlenmesinde Katalizör \\ Olarak Kullanılan Tungsten(VI) Oksit Destekli Rodyum(O) \\ Nanoparçacıkları
}

Research Article

Serdar Akbayrak

Department of Chemistry, Faculty of Arts and Science, Sinop University, Sinop, Turkey.

\section{A B S TR AC T}

hodium(III) ions were first impregnated on the surface of tungsten( $\mathrm{VI})$ oxide $\left(\mathrm{WO}_{3}\right)$ in aqueous solution and reduced with aqueous $\mathrm{NaBH}_{4}$ to form rhodium(0) nanoparticles (Rh NPs) on the surface of $\mathrm{WO}_{3}$. After the isolation of the Rh NPs $/ \mathrm{WO}_{3}$ catalyst by centrifugation, it was characterized by advanced analytical techniqu es. The results reveal the successful formation of Rh NPs on the surface of $\mathrm{WO}_{3}$. $\mathrm{Rh} \mathrm{NPs} / \mathrm{WO}_{3}$ catalyst with a turnover frequency value of $131^{\mathrm{h}-1}$ was found to be very active in hydrogenation of neat benzene at $25.0 \pm 0.1^{\circ} \mathrm{C}$.

\section{Key Words}

Tungsten(VI) oxide, rhodium nanoparticles, benzene, hydrogenation.

\section{Ö z}

odyum(III) iyonları ilk önce sulu çözelti içinde tungsten(VI) oksit $\left(\mathrm{WO}_{3}\right)$ üzerine tutturulmuş ve $\mathrm{WO}_{3}$ yüzeyi üzerinde rodyum(0) nanoparçacıkları (Rh NPs) oluşturmak için sulu $\mathrm{NaBH}_{4}$ ile indirgenmiştir. Rh NPs/WO katalizörü santrifüjleme ile ayrıldıktan sonra gelişmiş analitik tekniklerle tanımlanmıştır. Sonuçlar Rh NPs'nin

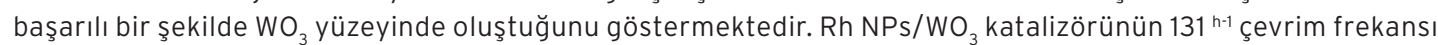
değeri ile $25.0 \pm 0.1^{\circ} \mathrm{C}^{\prime}$ de solventsiz benzen hidrojenlenmesinde çok aktif olduğu bulunmuştur

\section{Anahtar Kelimeler}

Tungsten(VI) oksit, rodyum nanoparçacıkları, benzen, hidrojenlenme.

Article History: Received: Apr 25, 2018; Revised: Jun 20, 2018; Accepted: Jul 6, 2018; Available Online: Oct 4, 2018

DOI: 10.15671/HJBC.2018.254

Correspondence to: S. Akbayrak, Department of Chemistry, Faculty of Arts and Science, Sinop University, Sinop, Turkey. 


\section{INTRODUCTION}

ydrogenation of benzene to cyclohexane has attracted great attention due to the use of cyclohexane for the production of nylon 6 and nylon $6.6[1,2]$. On the other hand, benzene is a toxic component of gasoline [3], which makes the hydrogenation of benzene in gasoline crucial. Therefore, there is a need for the development of highly active catalysts for the hydrogenation of benzene. Ruthenium [4], rhodium [1,3,5], platinum [6], iridium [7] nanoparticles are found to be effective catalysts for this industrially important reaction.

Since the metal nanoparticles tend to aggregate, various supporting materials such as carbon nanotube, silica, alumina and ceria are used to improve the catalytic activity and stability of these nanoparticles [8]. Tungsten( $\mathrm{VI}$ ) oxides $\left(\mathrm{WO}_{3}\right)$ are also considered as a suitable supporting material for metal nanoparticles. Indeed, ruthenium palladium, rhodium and platinum nanoparticles were successfully formed on $\mathrm{WO}_{3}$ based supporting materials $[9,10]$. Since tungsten $(\mathrm{VI})$ oxides are simply prepared and provide high chemical stability [11] they are widely used in many catalytic reactions such as oxidative desulfurization [12], dehydration of 2-Butanol [13], pentane isomerization [14] acetalization [15]. Recently, the promoting effect of $\mathrm{WO}_{3}$ on noble NPs used as catalysts in ethanol $[16,17]$, methanol [18] and CO [19] oxidations have been confirmed. On the other hand, tungsten(VI) oxides are considered to be used in hydrogenation reactions because the dissociation of $\mathrm{H}_{2}$ molecules to $\mathrm{H}^{+}$ionic species could easily be stabilized on $\mathrm{WO}_{3}$ structure [17].

Herein, the preparation, characterization and catalytic use of rhodium(0) nanoparticles (Rh NPs) supported on $\mathrm{WO}_{3}$ were reported. Rhodium(III) ions impregnated on the surface of tungsten( $\mathrm{VI}$ ) oxide were reduced by $\mathrm{NaBH}_{4}$ forming the Rh NPs/WO which was used as catalyst in hydrogenation of neat benzene. $\mathrm{RhNPs} / \mathrm{WO}_{3}$ was isolated from the reaction solution by centrifugation and characterized by ICPOES, XRD, TEM, TEM-EDX and BET techniques. Rh NPs were successfully prepared on the surface of $\mathrm{WO}_{3}$.

\section{MATERIALS and METHODS Materials}

Rhodium(III) chloride trihydrate $\left(\mathrm{RhCl}_{3} \cdot 3 \mathrm{H}_{2} \mathrm{O}\right)$, tungsten $(\mathrm{VI}),\left(\mathrm{WO}_{3}\right.$, particle size $\left.\approx 100 \mathrm{~nm}\right)$, sodium borohydride $\left(\mathrm{NaBH}_{4}, 98 \%\right)$ and benzene (99.9\%) were purchased from Aldrich.

\section{Preparation of Rh NPs supported on $\mathrm{WO}_{3}$}

In a $250 \mathrm{~mL}$ round bottom flask $400 \mathrm{mg}$ of $\mathrm{WO}_{3}$ was added to a solution of $\mathrm{RhCl}_{3} \cdot 3 \mathrm{H}_{2} \mathrm{O}(5.2 \mathrm{mg})$ in $100 \mathrm{~mL} \mathrm{H} \mathrm{H}_{2} \mathrm{O}$. This slurry was stirred at room temperature for $24 \mathrm{~h}$, then $\mathrm{NaBH}_{4}(6 \mathrm{mM}$ in 10 $\mathrm{mL} \mathrm{H}_{2} \mathrm{O}$ ) solution was added dropwise. After $1 \mathrm{~h}$ stirring Rh NPs/ $/ \mathrm{WO}_{3}$ were formed and the sample was isolated by centrifugation (at $8000 \mathrm{rpm}$ ) and washed with $50 \mathrm{~mL}$ of distilled water and the remnant was dried under vacuum at $60^{\circ} \mathrm{C}$ for 12 h. Rhodium content, determined by ICP-OES, was found as $0.39 \%$ wt. for $\mathrm{Rh} N \mathrm{NS} / \mathrm{WO}_{3}$. The sample was also characterized by XRD, TEM, TEM-EDX and $B E T$ techniques as described in a recent report [20].

\section{Hydrogenation Apparatus}

Hydrogenation reactions were carried out using a Fischer-Porter pressure bottle which are modified with Swagelock TFE-sealed quick connects. The reactor was connected to $\mathrm{a}_{2}$ gas tank. The gas pressure in the reactor was measured with a pressure transducer (Omega PX-302) coupled with a digital transmitter (Omega D1131) and RS-232 module. The data were transferred to a computer and the change of $\mathrm{H}_{2}$ pressure in the reactor was followed on Lab View 8.0 program.

\section{Hydrogenation of Neat Benzene Using Rh NPs Supported on $\mathrm{WO}_{3}$}

Hydrogenation of neat benzene was performed by following the procedure described elsewhere [21]. Before the hydrogenation experiments, the catalyst and the substrate were transferred into the reactor in the oxygen free dry box. In a typical experiment, $80 \mathrm{mg} \mathrm{Rh} \mathrm{NPs} / \mathrm{WO}_{3}(0.39 \%$ wt. $\mathrm{Rh})$ catalyst, $0.6 \mathrm{~mL}$ of neat benzene and magnetic stir bar were transferred into a test tube in the Fischer-Porter pressure bottle. After sealing the Fischer-Porter bottle in the oxygen free drybox, it was connected to the oxygen free hydrogenation 
line via its Swagelock connects. The temperature of the reaction was controlled by a water bath $\left(25.0 \pm 0.1^{\circ} \mathrm{C}\right)$. The hydrogenation reaction was followed on the computer using Lab View 8.0 program. The conversion of neat benzene was monitored by the hydrogen pressure loss in the reactor. The complete conversion of benzene was also confirmed by ${ }^{1} \mathrm{H}$-NMR. It is noteworthy that $\mathrm{WO}_{3}$ nanopowders without rhodium nanoparticles are found to be catalytically inactive in the hydrogenation of benzene at $25.0 \pm 0.1^{\circ} \mathrm{C}$.

\section{Reusability of Rh NPs/ $/ \mathrm{WO}_{3}$ in Hydrogenation of Neat Benzene}

After the complete hydrogenation of benzene started with $0.6 \mathrm{~mL}$ of neat benzene and $80 \mathrm{mg}$ of Rh NPs $/ \mathrm{WO}_{3}\left(0.39 \%\right.$ wt. Rh) at $25.0 \pm 0.1^{\circ} \mathrm{C}$, the Fischer-Porter bottle was taken into the dry box and kept there until the catalyst settle down at the bottom of the reactor. The supernatant was separated from the catalyst via a pipette and then $0.6 \mathrm{~mL}$ of neat benzene was transferred again into the reactor. Second run of the hydrogenation of benzene at $25.0 \pm 0.1^{\circ} \mathrm{C}$ was started again as described above.

\section{RESULTS and DISCUSSION}

Rhodium(0) nanoparticles supported on $\mathrm{WO}_{3}$ were prepared by the impregnation of $\mathrm{Rh}^{3+}$ ions on the surface of $\mathrm{WO}_{3}$, followed by their reduction with aqueous solution of $\mathrm{NaBH}_{4}$. Rh $\mathrm{NPs} / \mathrm{WO}_{3}$ was isolated from the reaction solution by centrifugation and characterized by ICP-OES, $X R D, B E T, T E M$ and TEM-EDX.
The XRD patterns of $\mathrm{WO}_{3}$ and $\mathrm{Rh} \mathrm{NPs} / \mathrm{WO}_{3}$ show that there is no change in the position of the characteristic diffraction peaks of tungsten( $\mathrm{VI})$ oxide after Rh loading (Figure 1). This observation indicates that $\mathrm{WO}_{3}$ remains intact after the impregnation and reduction of $\mathrm{Rh}^{3+}$ ions on the surface of tungsten(VI) oxide powder. However, there exists no XRD peaks attributed to the rhodium NPs in Fig. 1 due to the low Rh loading on $\mathrm{WO}_{3}$ powder. Indeed, the rhodium loading determined by ICP-OES was found as $0.39 \%$ wt. which is below than the detection limit of XRD.

The BET nitrogen adsorption analysis (Figure 2) gave the surface area of $\mathrm{WO}_{3}$ and Rh NPs/ $\mathrm{WO}_{3}\left(0.39 \%\right.$ wt. Rh) as $9.7 \mathrm{~m}^{2} / \mathrm{g}$ and $11.2 \mathrm{~m}^{2} / \mathrm{g}$, respectively. The larger surface area of Rh NPs/ $\mathrm{WO}_{3}$ may be attributed to the presence of Rh NPs on the surface of $\mathrm{WO}_{3}$ powder. The presence of Rh NPs on $\mathrm{WO}_{3}$ was also investigated by TEM and TEM-EDX analyses. Indeed, the TEM image of Rh NPs $/ \mathrm{WO}_{3}$ $(0.39 \%$ wt. Rh) given in Fig.3a shows that Rh NPs were successfully formed on the surface of $\mathrm{WO}_{3}$. TEM-EDX (Figure $3 \mathrm{~b}$ ) provides the confirmation of the existence of Rh NPS on $\mathrm{WO}_{3}$.

The catalytic activity of Rh NPs/ $\mathrm{WO}_{3}$ was tested in hydrogenation of neat benzene under $\sim 3$ bar pressure of $\mathrm{H}_{2}$ gas at $25.0 \pm 0.1^{\circ} \mathrm{C}$. The hydrogenation of solvent free benzene was monitored by hydrogen uptake which was converted to the loss of benzene concentration (Figure 4) using stoichiometric calculations. The total conversion of benzene to cvclohexane was achieved after $45 \mathrm{~h}$ at $25.0 \pm 0.1^{\circ} \mathrm{C}$.

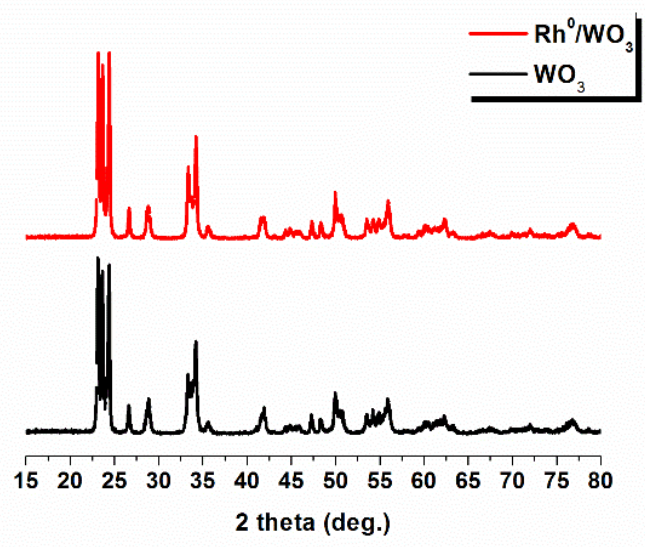

Figure 1. XRD patterns of $\mathrm{WO}_{3}$ and $\mathrm{Rh} \mathrm{NPs} / \mathrm{WO}_{3}(0.39 \%$ wt. Rh). 

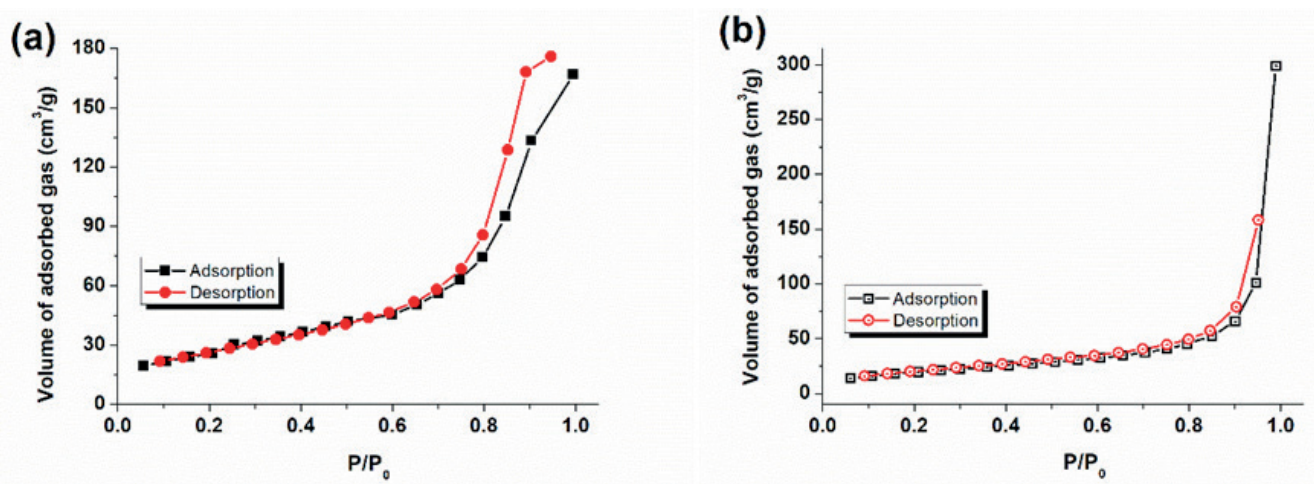

Figure 2. The nitrogen adsorption-desorption isotherms of (a) $\mathrm{WO}_{3}$ and (b) Rh NPs/ $\mathrm{WO}_{3}(0.39 \%$ wt. Rh).
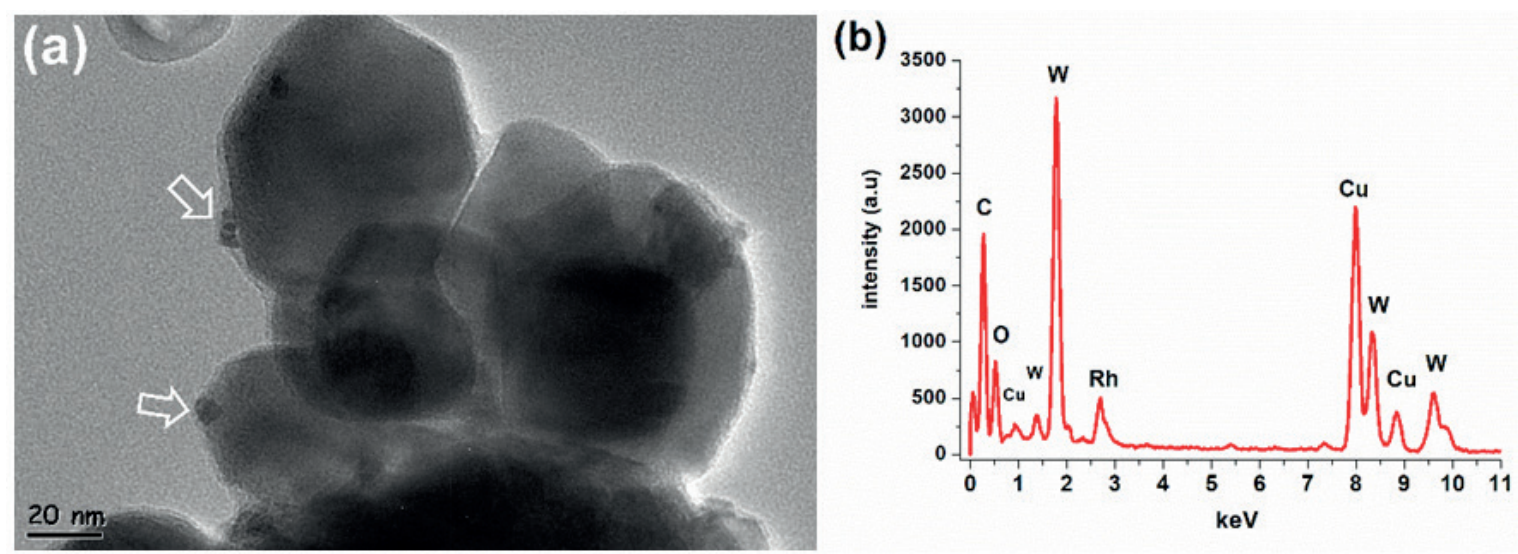

Figure 3. (a) TEM image and (b) TEM-EDX of Rh NPs/WO $(0.39 \%$ wt. Rh) (White arrows in figure a represent the Rh NPs).

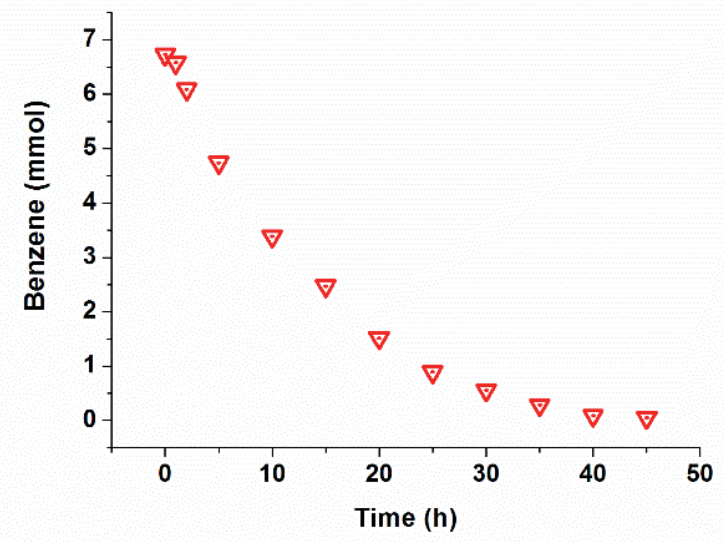

Figure 4. The plot of benzene consumption versus time using $80 \mathrm{mg}$ of $\mathrm{Rh} \mathrm{NPs} / \mathrm{WO}_{3}(0.39 \% \mathrm{wt}$. Rh) catalyst and $0.6 \mathrm{~mL}$ of neat benzene under 3 bar $\mathrm{H}_{2}$ pressure at $25.0 \pm 0.1^{\circ} \mathrm{C}$.

Rh NPs $/ \mathrm{WO}_{3}$ catalyst provided a TOF value of $131 \mathrm{~h}^{-1}$ at $25.0 \pm 0.1^{\circ} \mathrm{C}$ during $5 \mathrm{~h}$ in this reaction. Indeed, $\mathrm{Rh}$ $\mathrm{NPs} / \mathrm{WO}_{3}$ was found to be highly active catalyst as compared to most of the reported catalyst given in Table 1 such as Rh/fluorous hybrid silica [31], Rh/ CNT [26], Rh/BMI.PF ${ }_{6}$ [33], $\mathrm{Rh} / \mathrm{SiO}_{2}$ [27], $\mathrm{Rh}(\mathrm{COD})$ $\mathrm{Cl}_{2}$ [32], $\mathrm{PtO}_{2}$ [43] and Pt NPs [43]. It is noteworthy that the reaction conditions such as temperature, pressure and solvent show variations for the reported catalysts, which makes the comparison of the catalytic activities of these catalysts difficult. However, the catalytic activity of the Rh NPs/ $/ \mathrm{WO}_{3}$ catalyst under low pressure, low temperature in solvent free medium makes Rh NPs/ $/ \mathrm{WO}_{3}$ advantageous over most of the reported catalysts. 
Table 1. Catalytic performance of various catalysts for benzene hydrogenation. Turnover frequency (TOF) values in references were described as (mol cyclohexane) $\times(\text { mol metal) })^{-1} \times \mathrm{h}^{-1}$

\begin{tabular}{|c|c|c|c|c|c|}
\hline Catalyst & $\begin{array}{c}\text { Temperature } \\
\left({ }^{\circ} \mathrm{C}\right)\end{array}$ & $\begin{array}{c}\text { Pressure of } \mathrm{H}_{2} \\
\text { (bar) }\end{array}$ & $\begin{array}{l}\text { TOF } \\
\left(h^{-1}\right)\end{array}$ & Solvent & Ref. \\
\hline $2 \% \mathrm{Rh} / \mathrm{NZ}-\mathrm{CP}$ & 60 & 10 & 25765.5 & neat benzene & 1 \\
\hline $\mathrm{Rh} / \mathrm{HAp}$ & 25 & 3 & 1770 & neat benzene & 2 \\
\hline $\mathrm{Rh} / \mathrm{AlO}(\mathrm{OH})$ & 75 & 4 & 1700 & neat benzene & 3 \\
\hline Rh/MWNTs & 20 & 10 & 1038 & neat benzene & 4 \\
\hline $\mathrm{Pd}-\mathrm{Rh} / \mathrm{CNT}$ & 20 & 10 & 592.6 & neat benzene & 5 \\
\hline $\mathrm{Rh} / \mathrm{TiO}_{2}$ & 25 & 1 & 476 & water/benzene & 6 \\
\hline Rh NPs/CDG & 50 & 4 & 310 & neat benzene & 7 \\
\hline $\mathrm{Rh} / \mathrm{PVP}$ & 30 & 7 & 250 & water/benzene & 8 \\
\hline Rh NPs/CDG & 25 & 4 & 228 & neat benzene & 28 \\
\hline $\mathrm{Rh} / \mathrm{Fe}_{3} \mathrm{O}_{4} / \mathrm{SiO}_{2}-\mathrm{NH}_{2}$ & 25 & 6 & 196 & neat benzene & 9 \\
\hline $\mathrm{Rh} \mathrm{NPs} / \mathrm{WO}_{3}$ & 25 & 3 & 131 & neat benzene & $\begin{array}{l}\text { This } \\
\text { study }\end{array}$ \\
\hline $\mathrm{Rh} / \mathrm{CNT}$ & 20 & 10 & 118.1 & neat benzene & 26 \\
\hline $\mathrm{Rh} / \mathrm{SiO}_{2}$ & 25 & 1 & 113 & water/benzene & 27 \\
\hline $\begin{array}{l}\text { Rh (2 mol\%) / } \\
\text { fluorous } \\
\text { hybrid silica }\end{array}$ & 60 & 1 & 111 & 2-propanol & 10 \\
\hline $\begin{array}{l}\mathrm{Rh}(\mathrm{COD}) \mathrm{Cl}_{2} \\
\text { (rhodium nanopar- } \\
\text { ticles) }\end{array}$ & 25 & 1 & 16 & neat benzene & 11 \\
\hline $\mathrm{Rh} / \mathrm{BMI} \mathrm{PF}{ }_{6}$ & 75 & 4 & 11 & $\begin{array}{l}\text { BMI.PF }{ }_{6} / \text { ben- } \\
\text { zene }\end{array}$ & 12 \\
\hline $\mathrm{Ru}_{0.04} \mathrm{Ni}_{0.96} / \mathrm{C}(30)$ & 60 & 53 & 13522.4 & neat benzene & 13 \\
\hline $\begin{array}{l}\text { Ru/Mesoporous } \\
\text { Carbon }\end{array}$ & 110 & 40 & 35112 & neat benzene & 14 \\
\hline Ru@graphite oxide & 100 & 10 & 34331 & neat benzene & 15 \\
\hline Ru-B/MIL-53(AICr) & 30 & 10 & 23040 & ethanol & 16 \\
\hline $\mathrm{Ru} / \mathrm{CNTS}$ & 80 & 40 & 6983 & neat benzene & 17 \\
\hline Ru/porous carbon & 110 & 40 & 5544 & neat benzene & 18 \\
\hline $0.27 \%$ Ru/Zeolite & 25 & 2.9 & 5430 & neat benzene & 4 \\
\hline $\mathrm{Ru} / \mathrm{SiO}_{2}$ & 100 & 20 & 5000 & neat benzene & 19 \\
\hline Ru-MOF_Mt & 160 & 60 & 3478 & neat benzene & 20 \\
\hline $\mathrm{Ru} / \mathrm{SBA}-15$ & 110 & 40 & 974 & neat benzene & 35 \\
\hline $\begin{array}{l}\text { Ru (2 mol \%) / } \\
\text { fluorous } \\
\text { hybrid silica }\end{array}$ & 60 & 1 & 29 & 2-propanol & 31 \\
\hline Ir/Graphite oxide & 100 & 10 & 10000 & neat benzene & 21 \\
\hline Ir/Zeolite & 25 & 3 & 3190 & neat benzene & 21 \\
\hline $\mathrm{Pt}(0) \mathrm{NPs}$ & 75 & 4 & 28 & neat benzene & 22 \\
\hline $\mathrm{PtO}_{2}$ & 75 & 4 & 2 & neat benzene & 43 \\
\hline
\end{tabular}


(a)

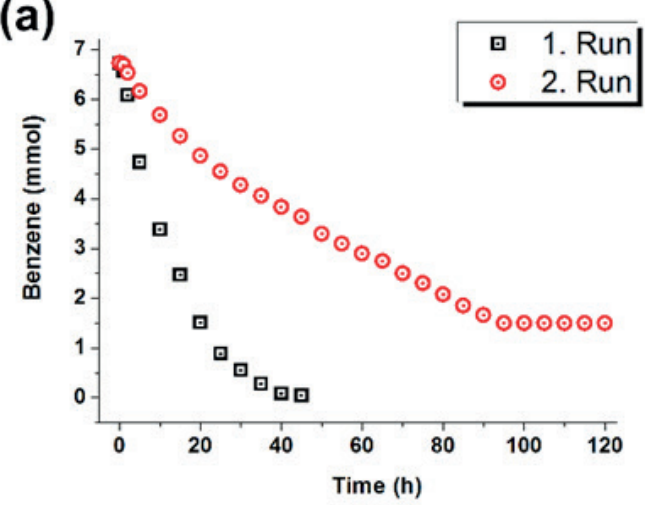

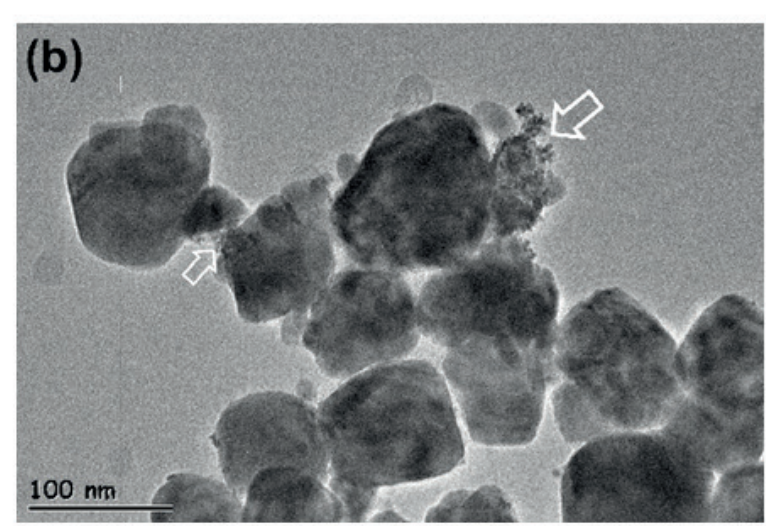

Figure 5. (a) Graph of benzene consumption versus time for the first and second use of Rh NPs/WO $(0.39 \%$ wt. Rh) catalyst in hydrogenation of benzene at $25.0 \pm 0.1^{\circ} \mathrm{C}$, (b) TEM image of Rh NPs $/ \mathrm{WO}_{3}$ catalyst $(0.39 \%$ wt. Rh) taken after the second use (White arrows in figure b represent the aggregation of Rh NPs).

The reusability of $\mathrm{Rh} \mathrm{NPs} / \mathrm{WO}_{3}$ catalyst was also investigated in hydrogenation of neat benzene under 3 bar $\mathrm{H}_{2}$ pressure at $25.0 \pm 0.1^{\circ} \mathrm{C}$. The reusability test reveals that $\mathrm{Rh} \mathrm{NPs} / \mathrm{WO}_{3}$ catalyst loses its activity during the second use (Figure $5 \mathrm{a}$ ). It provides no activity after $90 \mathrm{~h}$. After the second use, $\mathrm{Rh} \mathrm{NPs} / \mathrm{WO}_{3}$ catalyst was isolated from the reaction solution by removing supernatant via a pipette and dried under vacuum at $60^{\circ} \mathrm{C}$ for $12 \mathrm{~h}$. The TEM image of Rh NPs/ $\mathrm{WO}_{3}$ catalyst taken after the second use shows the agglomeration of Rh NPs (Figure $5 b$ ), which could be the main reason of the catalytic activity loss.

\section{CONCLUSIONS}

Rhodium( 0 ) nanoparticles supported on $\mathrm{WO}_{3}$ was successfully prepared and characterized by using advanced analytical techniques such as ICP-OES, BET, XRD, TEM and TEM-EDX. Rh NPs/WO ${ }_{3}$ catalyst with a TOF value of $131 \mathrm{~h}^{-1}$ was found to be highly active in solventless hydrogenation of benzene to cyclohexane at $25.0 \pm 0.1^{\circ} \mathrm{C}$. However, Rh NPs/ $\mathrm{WO}_{3}$ catalyst provided poor reusability due to the aggregation of rhodium nanoparticles on the surface of $\mathrm{WO}_{3}$ after the first catalytic use. The facile and environmentally friendly preparation of the catalyst followed in this work can be extended to prepare other tungsten $(\mathrm{VI})$ oxide supported noble or non-noble metal catalysts such as ruthenium, palladium, cobalt and nickel.

\section{Acknowledgements}

METU Central Lab (Ankara/Turkey) is gratefully acknowledged for the TEM, XRD, ICP-OES and BET analyses.

\section{References}

1. V. Mevellec, A. Nowicki, A. Roucoux, C. Dujardin, P. Granger, E. Payen, K. Philippot, A simple and reproducible method for the synthesis of silicasupported rhodium nanoparticles and their investigation in the hydrogenation of aromatic compounds, New J. Chem., 30 (2006) 1214-1219.

2. H. Liu, R. Fang, Z. Li, Y. Li, Solventless hydrogenation of benzene to cyclohexane over a heterogeneous RuPt bimetallic catalyst, Chemical Eng. Sci., 122 (2015) 350-359.

3. C. Vangelis, A. Bouriazos, S. Sotiriou, M. Samorski, B. Gutsche, G. Papadogianakis, Catalytic conversions in green aqueous media: Highly efficient biphasic hydrogenation of benzene to cyclohexane catalyzed by Rh/TPPTS complexes, J. Catal., 274 (2010) 21-28.

4. M. Zahmakıran, Y. Tonbul, S. Özkar, Ruthenium(0) Nanoclusters Stabilized by a Nanozeolite Framework: Isolable, Reusable, and Green Catalyst for the Hydrogenation of Neat Aromatics under Mild Conditions with the Unprecedented Catalytic Activity and Lifetime, J. Am. Chem. Soc., 132 (2010) 65416549.

5. H.B.Pan, C.M. Wai, Sonochemical One-Pot Synthesis of Carbon Nanotube-Supported Rhodium Nanoparticles for Room-Temperature Hydrogenation of Arenes, J. Phys. Chem. C., 113 (2009) 19782-88.

6. H.B. Pan, C.M. Wai, Facile sonochemical synthesis of carbon nanotube-supported bimetallic Pt-Rh nanoparticles for room temperature hydrogenation of arenes, New J. Chem., 35 (2011) 1649-1660.

7. F. Li, B.C. Gates, Size-Dependent Catalytic Activity of Zeolite-Supported Iridium Clusters, J. Phys. Chem. C, 111 (2007) 262-267.

8. S. Akbayrak, S. Özkar, Hydrogen Generation from the Hydrolysis of Ammonia Borane Using Transition Metal Nanoparticles as Catalyst, in: Hydrogen Production Technologies, Wiley-VCH, Weinheim, Germany, 2017.

9. N. Li, Y. Zheng, L. Wei, H. Teng, J. Zhou, Metal nanoparticles supported on $\mathrm{WO}_{3}$ nanosheets for highly selective hydrogenolysis of cellulose to ethylene glycol, Green Chem., 19 (2017) 682-691. 
10. S.J. Kim, S.J. Choi, J.S. Jang, N.H. Kim, M. Hakim, H L. Tuller, I.D. Kim, Mesoporous $\mathrm{WO}_{3}$ Nanofibers with Protein- Templated Nanoscale Catalysts for Detection of Trace Biomarkers in Exhaled Breath, ACS Nano, 10 (2016) 5891-5899.

11. M.S. Tsaia, C.J. Lua, P.G. Su, One-pot synthesis of AuNPs/RGO/ $\mathrm{WO}_{3}$ nanocomposite for simultaneously sensing hydroquinone and catechol, Mater. Chem. Phys., 215 (2018) 293-298

12. G.R. Gattorno, A. Galano, E. Torres-Garcia, Surface acid-basic properties of $\mathrm{WO}_{x}-\mathrm{ZrO}_{2}$ and catalytic efficiency in oxidative desulfurization, Appl. Catal. B, 92 (2009) 1-8.

13. C.D. Baertsch, K.T. Komala, Y.H. Chua, E. Iglesia, Genesis of Brønsted Acid Sites during Dehydration of 2-Butanol on Tungsten Oxide Catalysts, J. Catal., 205 (2002) 44-57.

14. M. Scheithauer, T.K. Cheung, R.E. Jentoft, R.K. Grasselli, B.C. Gates, H. Knözinger, Characterization of $\mathrm{WO}_{\mathrm{x}} / \mathrm{ZrO}_{2}$ by Vibrational Spectroscopy and $\mathrm{n}$-Pentane Isomerization Catalysis, J. Catal., 180 (1998) 1-13.

15. P. Wang, J. Feng, Y. Zhao, S. Wang, J. Liu, MOFDerived Tungstated Zirconia as Strong Solid Acids toward High Catalytic Performance for Acetalization. ACS Appl. Mater. Interfaces, 8 (2016) 23755-23762.

16. K. Miecznikowski, Enhancement of activity of PtRh nanoparticles towards oxidation of ethanol through modification with molybdenum oxide or tungsten oxide. J Solid State Electrochem, 16 (2012) 2723-2731.

17. I.R. Rutkowska, A. Wadas, P.J. Kulesza, Mixed layered $\mathrm{WO}_{3} / \mathrm{ZrO}_{2}$ films (with and without rhodium) as active supports for PtRu nanoparticles: enhancement of oxidation of ethanol, Electrochimica Acta, 210 (2016) 575-587.

18. P.J. Barczuk, H. Tsuchiya, J.M. Macak, P. Schmuki, D. Szymanska, O. Makowski, K. Miecznikowski, P.J. Kulesza, Enhancement of the Electrocatalytic Oxidation of Methanol at $\mathrm{Pt} / \mathrm{Ru}$ Nanoparticles Immobilized in Different $\mathrm{WO}_{3}$ Matrices, Electrochem. Solid-State Lett., 9 (2006) E13-E16.

19. F. Micoud, F. Maillard, A. Bonnefont, N. Job, M. Chatenet, The role of the support in $\mathrm{CO}_{\text {ads }}$ monolayer electrooxidation on Pt nanoparticles: $\mathrm{Pt} / \mathrm{WO}_{\mathrm{x}}$ vs. Pt/C Phys. Chem. Chem. Phys., 12 (2010) 1182-1193.

20. S. Akbayrak, Y. Tonbul, S. Özkar, Ceria supported rhodium nanoparticles: Superb catalytic activity in hydrogen generation from the hydrolysis of ammonia borane, Appl. Catal. B, 198 (2016) 162-170.

21. Y. Tonbul, M. Zahmakiran, S. Özkar, Iridium(0) nanoparticles dispersed in zeolite framework: A highly active and long-lived green nanocatalyst for the hydrogenation of neat aromatics at room temperature, Appl. Catal. B, 148-149 (2014) 466-472.

22. S.M. Baghbanian, M. Farhang, S.M. Vahdat, M. Tajbakhsh, Hydrogenation of arenes, nitroarenes, and alkenes catalyzed by rhodium nanoparticles supported on natural nanozeolite clinoptilolite, J. Mol. Catal. A Chem., 407 (2015) 128-136.

23. M. Zahmakiran, Y. Roman-Leshkov, Y. Zang, Rhodium(0) Nanoparticles Supported on Nanocrystalline Hyroxyapatite: Highly Effective Catalytic System for the Solvent- Free Hydrogenation of Aromatics at Room Temperature, Langmuir, 28 (2012) 60-64
24. I.S. Park, M.S. Kwon, K.Y. Kang, J.S. Lee, J. Parka, Rhodium and Iridium Nanoparticles Entrapped in Aluminum Oxyhydroxide Nanofibers: Catalysts for Hydrogenations of Arenes and Ketones at Room Temperature with Hydrogen Balloon, Adv. Synth. Catal., 349 (2007) 2039-2047.

25. H.B. Pan, C.M. Wai, Sonochemical one-pot synthesis of carbon nanotube supported rhodium nanoparticles for room-temperature hydrogenation of arenes, J. Phys. Chem. C, 113 (2009) 19782-19788.

26. B. Yoon, H.B. Pan, C.M. Wai, Relative catalytic activities of carbon nanotube supported metallic nanoparticles for room-temperature hydrogenation of benzene, J. Phys. Chem. C, 113 (2009) 1520-1525.

27. C. Hubert, E. G.Bile, A. Denicourt-Nowicki, A. Roucoux, $\mathrm{Rh}(0)$ colloids supported on $\mathrm{TiO}_{2}$ : a highly active and pertinent tandem in neat water for the hydrogenation of aromatics Green Chem., 13 (2011)1766-1771.

28. D. Marquardt, C. Vollmer, R. Thomann, P. Steurer, R. Mülhaupt, E. Redel, C. Janiak, The use of microwave irradiation for the easy synthesis of graphenesupported transition metal nanoparticles in ionic liquids, Carbon, 49 (2011) 1326-1332.

29. J. Pellegatta, C. Blandy, V. ColliRre, R. Choukroun, B. Chadret, P. Cheng, K. Philippot, Catalytic investigation of rhodium nanoparticles in hydrogenation of benzene and phenylacetylene, J. Mol. Catal. A ,178 (2002) 55-61.

30. M.J. Jacinto, P.K. Kiyohara, S.H. Masunaga, R.F. Jardim, L.M. Rossi, Recoverable rhodium nanoparticles: Synthesis, characterization and catalytic performance in hydrogenation reactions Appl. Catal. A, 338 (2008) 52-57.

31. S. Niembro, S. Donnici, A. Shafir, A. Vallribera, M.L. Buil, M.A. Esteruelas, C. Larramona, Perfluoro-tagged rhodium and ruthenium nanoparticles immobilized on silica gel as highly active catalysts for hydrogenation of arenes under mild conditions, New J. Chem., 37 (2013) 278-282.

32. M.H. Seeberger, R.A. Jones, Synthesis of Polymersupported Transition Metal Catalysts via Phosphido Linkages:Heterogeneous Catalysts for the Hydrogenation of Aromatic Compounds under Mild Conditions, J. Chem. Soc. Chem. Comm., 6 (1985) 373.

33. G. S. Fonseca, A.P. Umpierre, P. F. P. Fichtner, S.R. Teixeira, J. Dupont, The Use of Imidazolium Ionic Liquids for the Formation and Stabilization of $\mathrm{Ir}^{\circ}$ and $\mathrm{Rh}^{\circ}$ Nanoparticles: Efficient Catalysts for the Hydrogenation of Arenes, Chem. Eur. J., 9 (2003) 3263-3269.

34. L. Zhu, H. Sun, J. Zheng, C. Yu, N. Zhang, Q. Shu, B. $\mathrm{H}$. Chen, Combining $\mathrm{Ru}, \mathrm{Ni}$ and $\mathrm{Ni}(\mathrm{OH})_{2}$ active sites for improving catalytic performance in benzene hydrogenation, Mater. Chem. Phys., 192 (2017) 8-16.

35. Y. Li, G. Lan, H. Wang, H. Tang, X. Yan, H. Liu, Controlled synthesis of highly dispersed semi-embedded ruthenium nanoparticles in porous carbon framework with more exposed active sites, Catal. Commun., 20 (2012) 29-35.

36. R.M. Esteban, K. Schütte, D. Marquardt, J. Barthel, F. Beckert, R. Mülhaupt, C. Janiak, Synthesis of ruthenium@graphene nanomaterials in propylene carbonate as re-usable catalysts for the solvent-free hydrogenation of benzene, Nano-Structures NanoObjects, 2 (2015) 28-34. 
37. H. Bi, X. Tan, R. Dou, Y. Pei, M. Qiao, B. Sun, B. Zong, $\mathrm{Ru}-\mathrm{B}$ nanoparticles on metal-organic frameworks as excellent catalysts for hydrogenation of benzene to cyclohexane under mild reaction conditions, Green Chem., 18 (2016) 2216-2221.

38. Y.Ma, Y. Huang, Y. Cheng, L. Wang, X. Li, Biosynthesized ruthenium nanoparticles supported on carbon nanotubes as efficient catalysts for hydrogenation of benzene to cyclohexane: an eco-friendly and economical bioreduction method, Appl. Catal. A, 484 (2014) 154-160.

39. F.B. Su, F.Y. Lee, L. Lv, J.J. Liu, X.N. Tian, X.S. Zhao, Sandwiched ruthenium/carbon nanostructures for highly active heterogeneous hydrogenation, Adv. Funct. Mater., 17 (2007) 1926-1931.

40. X. Kang, J. Zhang, W. Shang, T. Wu, P. Zhang, B. Han, Z. Wu, G. Mo, X. Xing, One-step synthesis of highly efficient nanocatalysts on the supports with hierarchical pores using porous ionic liquid-water gel, J. Am. Chem. Soc., 136 (2014) 3768-3771.
41. D. Chen, M. Huang, S. He, S. He, L. Ding, Q. Wang, S. $\mathrm{Yu}, \mathrm{S}$. Miao, Ru-MOF enwrapped by montmorillonite for catalyzing benzene hydrogenation, Appl. Clay Sci., 119 (2016) 109-115.

42. R.M. Esteban, K. Schütte, P. Brandt, D. Marquardt, H. Meyer, F. Beckert, R. Mülhaupt, H. Kölling, C. Janiak, Iridium@graphene composite nanomaterials synthesized in ionic liquid as re-usable catalysts for solvent-free hydrogenation of benzene and cyclohexene, Nano-Structures \& Nano-Objects 2 (2015) 11-18.

43. C.W. Scheeren, G. Machado, J. Dupont, P.F.P. Fichtner, S.R. Texeira, Nanoscale Pt(0) Particles Prepared in Imidazolium Room Temperature Ionic Liquids: Synthesis from an Organometallic Precursor, Characterization, and Catalytic Properties in Hydrogenation Reactions, Inorg. Chem., 42 (2003) 4738-4742. 